\title{
PROFIL KEPALA DAERAH DAN KINERJA PENYELENGGARAAN PEMERINTAH DAERAH
}

\author{
Ari Kuncara Widagdo \\ Fakultas Ekonomi dan Bisnis, Universitas Sebelas Maret Surakarta \\ Widagdo2002@yahoo.com \\ Moh. Badrul Munir \\ Badan Pengawasan Daerah, Kabupaten Pacitan \\ munir.ardhi@gmail.com
}

\begin{abstract}
This study aims to determine the effect of the profiles of local government heads on local government performance. In this research, the profiles of local government heads consists of working experience, competence, and the strength of legislative oversight. We also control for other variables, namely: size, wealth, leverage, the strength of public oversight, and the quality of financial statements, all at the local government level. This study relies on a mixed method that combines qualitative and quantitative approaches in order to generate more comprehensive results. We focus on all 38 districts/ municipalities in the East Java Province for the years 2009-2013, resulting in 152 district-year observations. Our multiple regression analysis indicates that all profiles of local government heads have no significant effects on local government performance. Our interview clarifies further our previous findings. Regarding the control variables, local government size, the strength of public oversight and the financial reporting quality have significant effects on local government performance.
\end{abstract}

Keywords: local government performance, mixed method, profile of local government heads.

\begin{abstract}
ABSTRAK
Penelitian ini bertujuan untuk mengetahui pengaruh profil dari kepala pemerintah daerah terhadap kinerja pemerintah daerah. Profil terdiri dari pengalaman kerja, kompetensi, dan pengawasan oleh legislatif. Selain variabel-variabel tersebut, penelitian ini meneliti beberapa variabel kontrol seperti ukuran pemerintah daerah, kekayaan pemerintah daerah, leverage, pengawasan masyarakat, dan kualitas laporan keuangan pemerintah daerah. Penelitian ini menggunakan metode penelitian campuran yang menggabungkan pendekatan kualitatif dan kuantitatif untuk mendapatkan hasil yang lebih komprehensif. Penelitian ini menggunakan regresi berganda untuk menganalisis data dalam pendekatan kuantitatif, sedangkan metode wawancara digunakan dalam pendekatan kualitatif. Data mencakup semua kabupaten/kota di Provinsi Jawa Timur, yaitu 38 kabupaten/kota, dan periode pengamatan adalah 2009 sampai 2013. Terdapat 152 laporan keuangan pemerintah daerah yang diteliti dalam penelitian ini. Hasil penelitian menunjukkan bahwa semua variabel yang terkait dengan profil dari kepala pemerintah daerah (pengalaman kerja, kompetensi, dan
\end{abstract}


pengawasan oleh legislatif) tidak memiliki hubungan yang signifikan dengan kinerja pemerintah daerah. Dalam analisis lebih lanjut, hasil wawancara memberikan klarifikasi lebih lanjut efek dari variabel-variabel ini. Dalam hal variabel kontrol, beberapa variabel seperti ukuran pemerintah daerah, leverage, pengawasan masyarakat, dan kualitas laporan keuangan memiliki pengaruh yang signifikan terhadap kinerja pemerintah daerah.

Kata kunci: kinerja pemerintah daerah, metode campuran, profil kepala pemerintah daerah.

\section{PENDAHULUAN}

Pelaksanaan otonomi daerah diawali pada tahun 2001 dan telah membawa perkembangan yang signifikan dalam tata kelola kepemerintahan di Indonesia. Otonomi daerah berlandaskan Undang-Undang (UU) Nomor 22 Tahun 1999 yang diperbarui dengan UU No. 32 Tahun 2004 tentang Pemerintah Daerah dan UU No. 25 Tahun 1999 yang kemudian diperbarui dengan UU No. 33 Tahun 2004 tentang Perimbangan Keuangan Pemerintah Pusat dan Daerah. Otonomi daerah merupakan hak, wewenang dan kewajiban daerah otonom untuk mengatur dan mengurus sendiri urusan pemerintahan dan kepentingan masyarakat setempat sesuai dengan peraturan perundang-undangan (UU No. 32 Tahun 2004). Pelaksanaan otonomi daerah mendorong terjadinya perubahan lingkungan baik lingkungan ekonomi, politik, sosial dan budaya. Perubahan tersebut menuntut peningkatan kualitas pelayanan publik yang lebih baik, pelaksanaan pembangunan daerah yang lebih terarah dan transparansi serta akuntabilitas dalam pelaksanaan jalannya pemerintahan sesuai dengan aturan yang berlaku.

Kinerja mendapat perhatian khusus bagi para praktisi bidang bisnis, maupun sektor publik. Pada sektor bisnis, kinerja dikaitkan dengan kinerja keuangan memiliki implikasi bagi kesehatan suatu organisasi yang berhubungan dengan keberlangsungan dari suatu perusahaan (Almajali et al., 2012). Kinerja yang tinggi menunjukkan/mencerminkan efektivitas manajemen dan efisiensi dalam memanfaatkan sumber daya perusahaan dan memberikan kontribusi untuk perekonomian negara pada umumnya. Hal ini selaras dengan pernyataan dari Greiling (2005) yang menyatakan bahwa pengukuran kinerja merupakan salah satu kunci sukses dari pembaharuan sektor publik. Lebih lanjut, De Bruijn (2002) menyebutkan bahwa pengukuran kinerja akan membawa transparansi, insentif untuk kinerja, dan pertanggungjawaban (akuntabilitas) terhadap kinerja.

Otonomi daerah memberikan kewenangan yang lebih besar kepada pemerintah daerah untuk mengatur dan mengurus sendiri urusan pemerintahan sesuai dengan peraturan perundang-undangan. Dalam pelaksanaan otonomi daerah, terdapat hubungan antara masyarakat dengan pemerintah, legislatif dengan pemerintah, dan masyarakat dengan legislatif, sehingga hubungan tersebut menyebabkan perbedaan kepentingan masing-masing peran yang mengakibatkan adanya konflik yang disebut 
sebagai agency conflict (Arifianti et al., 2013). Seperti yang terjadi di kabupaten/kota di Jawa Timur, masih terdapat keterlambatan dalam penetapan APBD. Tercatat pada tahun anggaran 2011 terdapat 15 kabupaten/kota, tahun 2012 sebanyak 15 kabupaten/kota yang tidak tepat waktu dalam penetapan APBDnya (setelah 31 Desember) (Mukjizat 2015). Keterlambatan penetapan APBD ini juga mengakibatkan tidak tercapainya realisasi penyerapan anggaran. Penyerapan anggaran yang tidak optimal ini menjadikan kinerja anggaran sangat memprihatinkan. Seperti halnya yang terjadi di pemkot Surabaya sampai dengan bulan Juni penyerapan APBD 2011 baru mencapai 35,94 persen (Ilmie 2011), sehingga mengakibatkan peningkatan penyerapan anggaran naik drastis dan menumpuk pada akhir tahun anggaran. Untuk itu, di akhir tahun anggaran, pemerintah daerah berusaha melakukan percepatan realisasi anggaran. Percepatan tersebut akan mengakibatkan menurunya kualitas penyerapan dan banyaknya kegiatan yang tidak produktif.

Apabila rendahnya penyerapan anggaran tersebut terus berlanjut, hal ini akan menganggu pertumbuhan ekonomi, penyerapan tenaga kerja dan pengentasan kemiskinan yang menjadi sasaran kebijakan fiskal secara khusus (Ilmie 2011). Rendahnya penyerapan ini terus terjadi dari tahun ke tahun. Buktinya, pada tahun 2013, penyerapan anggaran pendapatan dan belanja daerah (APBD) di Kabupaten Trenggalek Jawa Timur memasuki bulan November 2013 masih berada pada kisaran 50 persen dari total anggaran yang dialokasikan, yaitu lebih dari Rp1 triliun (Destyan 2013). Rendahnya penyerapan anggaran APBD juga disoroti oleh Forum Indonesia untuk Transparansi Anggaran (FITRA) Jawa Timur. Sampai dengan triwulan ketiga tahun anggaran 2013, Pemkot Surabaya baru menyerap anggaran sebesar 22 persen (Ali 2014). Dari pemaparan di atas dapat disimpulkan bahwa rendahnya penyerapan anggaran merupakan bukti nyata buruknya kinerja (Hendri 2015).

Hasil pemeriksaan yang dilakukan oleh BPK menghasilkan sebuah temuan yang berkaitan dengan kelemahan Sistem Pengendalian Intern (SPI) dan ketidakpatuhan terhadap ketentuan perundang-undangan. Semakin tinggi angka temuan audit, maka menunjukkan semakin rendahnya kinerja suatu pemda (Mustikarini dan Fitriasari 2012). Hasil pemeriksaan BPK terhadap kab/kota provinsi Jawa Timur yang berkaitan dengan kelemahan SPI mulai tahun 2009 s/d 2013 masih menunjukkan nilai temuan yang lumayan tinggi, dan belum menunjukkan tanda-tanda penurunan yang signifikan seperti yang tertera dalam Tabel 1 dan Tabel 2. Hal ini mengindikasikan bahwa pemerintah daerah masih perlu meningkatkan kualitas dalam menyajikan suatu laporan keuangan yang wajar. Penyajian suatu laporan keuangan yang wajar merupakan gambaran dan hasil dari pertanggungjawaban keuangan yang lebih baik. 
Tabel 1

Kelompok Temuan Kelemahan Sistem Pengendalian Internal (SPI) atas Pemeriksaan Audit BPK LKPD Kab/Kota Provinsi Jawa Timur 2009 s/d 2013

\begin{tabular}{clccccc}
\hline No & \multicolumn{1}{c}{ Kelompok Temuan } & LHP & LHP & LHP & LHP & LHP \\
2009 & 2010 & 2011 & 2012 & 2013 \\
\hline 1 & $\begin{array}{l}\text { Kelemahan sistem pengendalian akuntansi dan } \\
\text { pelaporan }\end{array}$ & 133 & 113 & 127 & 113 & 136 \\
2 & $\begin{array}{l}\text { Kelemahan sistem pengendalian pelaksanaan } \\
\text { anggaran pendapatan dan belanja }\end{array}$ & 201 & 183 & 152 & 158 & 130 \\
\hline & Kelemahan struktur Pengendalian Intern & 77 & 74 & 67 & 38 & 43 \\
\hline & Jumlah & 411 & 370 & 346 & 309 & 309
\end{tabular}

Sumber : LHPS Tahun 2010 s/d 2014

Tabel 2

Kelompok Temuan Akibat Ketidakpatuhan terhadap Ketentuan Perundang-undangan atas Pemeriksaan Audit BPK, LKPD Pemda Kab/Kota Provinsi Jawa Timur 2009 s/d 2013

\begin{tabular}{|c|c|c|c|c|c|c|}
\hline \multirow{2}{*}{ No } & \multirow{2}{*}{ Kelompok Temuan } & LHP 2009 & LHP 2010 & LHP 2011 & LHP 2012 & \multirow{2}{*}{$\begin{array}{c}\text { LHP } 2013 \\
\text { Nilai (Juta Rp) }\end{array}$} \\
\hline & & \multicolumn{2}{|c|}{ Nilai (Juta Rp) Nilai (Juta Rp) } & Nilai (Juta Rp) & Nilai (Juta Rp) & \\
\hline 1 & Kerugian daerah & $7.291,09$ & $16.009,15$ & $54.071,26$ & $41.604,19$ & $118.449,53$ \\
\hline 2 & Potensi kerugian daerah & $151.114,11$ & $111.521,73$ & $124.535,20$ & $6.493,48$ & $85.653,22$ \\
\hline 3 & Kekurangan penerimaan & $24.937,87$ & $46.175,79$ & $16.469,79$ & $9.180,80$ & $42.488,91$ \\
\hline 4 & Aministrasi & - & - & - & - & - \\
\hline 5 & Ketidakhematan & $1.940,58$ & $2.510,44$ & $5.083,59$ & $3.796,85$ & 536,53 \\
\hline \multirow[t]{2}{*}{6} & Ketidakefektifan & $9.185,28$ & $31.975,50$ & $36.753,95$ & $47.116,40$ & $1.081,65$ \\
\hline & Jumlah & $194.468,93$ & $208.192,61$ & $236.913,79$ & $108.191,72$ & $248.209,84$ \\
\hline
\end{tabular}

Sumber : LHPS Tahun 2010 s/d 2014

Beragam penelitian terdahulu telah dilakukan baik itu di luar negeri maupun di dalam negeri terkait dengan faktor-faktor yang mempengaruhi kinerja. Beberapa peneliti di sektor bisnis telah meneliti mengenai karakteristik manajemen terhadap kinerja organisasi, misalnya Hambrick dan Mason (1984); Bamber et al. (2010); Balta et al. (2010); dan Wiersema dan Bantel (1992). Pada sektor publik beberapa peneliti telah mengkaitkan karakteristik kepala daerah dengan kinerja pemerintah daerah (Seeba et al., 2009). Penelitian Sutaryo dan Carolina (2014) mengkaitkan karakteristik eksekutif, seperti latar belakang ekonomi/akuntansi, umur kepala daerah dan karakteristik legislatif seperti ukuran DPRD dan komposisi DPRD dengan ketepatan waktu penetapan APBD. Penelitian lain dilakukan oleh Arifianti et al. (2013) yang menghubungkan fungsi pengawasan DPRD dengan kinerja penyelenggaraan pemda.

Penelitian mengenai karakteristik manajemen yang dihubungkan dengan latar belakang pendidikan ekonomi bisnis/akuntansi dan pengaruhnya terhadap kinerja organisasi menunjukkan hasil yang belum konsisten. Terdapat penelitian yang menyatakan bahwa latar belakang pendidikan ekonomi bisnis/akuntansi berpengaruh terhadap kinerja suatu organisasi (Bamber et al., 2010). Demikian juga, Sutaryo dan Carolina (2014) menyatakan bahwa latar belakang pendidikan ekonomi bisnis/akuntansi berpengaruh terhadap ketepatan waktu penetapan APBD. 
Sebaliknya, hasil penelitian lain tidak menemukan hubungan antara latar belakang pendidikan ekonomi bisnis/akuntansi dengan luas pengungkapan informasi lingkungan pada perusahaan-perusahaan di Indonesia (Suhardjanto 2010).

Penelitian mengenai fungsi pengawasan legislatif juga menunjukkan hasil yang belum konsisten. Sutaryo dan Carolina (2014) menyebutkan bahwa jumlah anggota DPRD maupun komposisi DPRD mempengaruhi besarnya pengawasan yang diberikan kepada pemerintah. Namun, penelitian yang dilakukan oleh Arifianti et al. (2013) mempunyai pendapat yang berbeda mengenai pengawasan legislatif. Hasil penelitian mereka menyebutkan bahwa pengawasan yang dilakukan oleh DPRD terhadap pemerintah daerah tidak memberikan dampak yang signifikan terhadap kinerja penyelenggaraan pemerintahan daerah atau kurang efektif. Dengan kata lain, anggota DPRD terpilih belum optimal dalam melakukan kinerja pengawasan.

Kinerja pemerintah daerah selain dipengaruhi oleh profil kepala daerah juga dipengaruhi oleh karakteristik pemerintah daerah. Faktor-faktor yang mempengaruhi karakteristik pemerintah daerah, menurut Suhardjanto dan Yulianingtyas (2011), adalah ukuran daerah, kesejahteran, functional differentiation, umur daerah, latar belakang pendidikan kepala daerah, dan intergovernmental revenue.

Penelitian mengenai pengaruh ukuran (aset) terhadap kinerja telah diteliti oleh beberapa peneliti, yaitu Haniffa dan Cooke (2005); Agiomirgianakis et al. (2006); Patrick (2007); Papadogonas (2007); Liargovas dan Skandalis (2010); Pervan dan Visic (2012); Almajali et al. (2012); Omondi dan Muturi (2013); Agustinus et al. (2008); Hasibuan (2009); dan Mustikarini dan Fitriasari (2012). Hasil penelitian mereka menyebutkan bahwa ukuran organisasi mempunyai pengaruh yang signifikan terhadap kinerja organisasi.

Penelitian mengenai jumlah anggota DPRD diteliti oleh Giligan dan Matsusaka (2001) yang mengkaitkan ukuran legislatif dengan belanja negara. Suhardjanto dan Yulianingtyas (2011) mengkaitkan ukuran legislatif dengan kepatuhan pengungkapan wajib. Penelitian lain dilakukan oleh Setyaningrum dan Syafitri (2012) yang mengkaitkan ukuran DPRD dengan pengungkapan laporan keuangan.

Faktor lain yang mempengaruhi kinerja pemerintah daerah adalah tingkat kemakmuran daerah. Tingkat kemakmuran daerah digambarkan sebagai tingkat pendapatan perkapita (Lasward et al., 2005). Di Indonesia, tingkat kemakmuran daerah diproksikan dengan Pendapatan Asli Daerah (PAD) (Setyaningrum dan Syafitri 2012). Beberapa penelitian terdahulu, misalnya Sularso dan Restianto (2011); Mustikarini dan Fitriasari (2012); Setyaningrum dan Syafitri (2012); Julitawati et al. (2012); dan Simanulang (2013) menyebutkan bahwa tingkat kekayaan (PAD) berpengaruh signifikan terhadap kinerja organisasi (Pemda).

Faktor lain yang mempengaruhi kinerja pemerintah daerah adalah leverage. Beberapa peneliti yang meneliti mengenai leverage adalah Lasward et al. (2005); Agiomirgianakis et al. (2006); Papadogonas (2007); Agustinus et al. (2008); 
Liargovas dan Skandalis (2010); Bhunia (2010); Almajali et al. (2012); Pervan dan Visic (2012); Omondi dan Muturi (2013); Dogan (2013); Gwey dan Karanja (2014); dan Ludjianto et al. (2014). Penelitian mereka menyimpulkan bahwa leverage mempunyai pengaruh signifikan terhadap kinerja organisasi. Sebaliknya, Khalifa dan Shafii (2013) menemukan bahwa tidak ada hubungan antara Debt to Equity Ratio (DER) dengan Return on Asset (ROA) perusahaan.

Kinerja penyelenggaraan pemda juga dipengaruhi oleh kualitas laporan keuangan. Beberapa penelitian mengenai kualitas pengelolaan keuangan ditunjukkan dengan hasil pemeriksaan BPK sebagai perwujudan kualitas pengelolaan keuangan sebuah entitas. Pada sektor bisnis, penelitian mengenai pengaruh kualitas laporan keuangan terhadap kinerja organisasi dilakukan oleh Farouk dan Hassan (2014); dan Mock et al. (2009). Pada sektor publik, penelitian mengenai pengaruh kualitas laporan keuangan terhadap kinerja pemda dilakukan oleh beberapa peneliti, misalnya Arifianti et al. (2013); dan Mustikarini dan Fitriasari (2012); serta Sudarsana dan Rahardjo (2013). Zirman dan Rosi (2010) mengkaitkan kepatuhan perundang-undangan terhadap akuntabilitas kinerja instansi pemerintah.

Faktor lain yang berpengaruh terhadap kinerja pemerintah daerah adalah pengawasan masyarakat yang berhubungan erat dengan tingkat kualitas pendidikan masyarakat yang ditunjukkan melalui Indek Pembangunan Manusia (IPM) (Arifianti et al., 2013). Pada sektor bisnis, penelitian mengenai pembangunan manusia dilakukan oleh Marimuthu et al. (2009) yang menghubungkan modal manusia dengan kinerja perusahaan. Pada sektor publik penelitian mengenai IPM dilakukan oleh Amaliah (2004) yang mengkaitkan IPM dengan kinerja ekonomi suatu daerah. Batafor (2011) mengkaitkan IPM dengan kinerja keuangan dan Essien (2012) mengeksplorasi pemerintahan dengan pembangunan manusia.

Berdasarkan uraian di atas dapat disimpulkan bahwa penelitian mengenai karakteristik kepala daerah pada sektor publik sudah dilakukan oleh beberapa peneliti seperti Seeba et al. (2009); Arifianti et al. (2013); dan Sutaryo dan Carolina (2014). Namun, penelitian mengenai profil kepala daerah yang dikaitkan dengan kinerja penyelenggaraan pemerintah daerah belum banyak dilakukan dan hasilnya masih belum konsisten. Selain itu, sebagian besar penelitian terdahulu dalam penelitiannya menggunakan metode kuantitatif.

\section{KAJIAN PUSTAKA DAN PERUMUSAN HIPOTESIS}

\section{Kinerja Penyelenggaraan Pemerintahan Daerah}

Kinerja Penyelenggaraan Pemerintah daerah (KPPD) menurut Permendagri 73 tahun 2009 tentang Tata Cara Pelaksanaan Evaluasi Kinerja Penyelenggaraan Pemerintah Daerah adalah capaian atas penyelenggaraan urusan pemerintahan daerah yang diukur dari masukan, proses, keluaran, hasil, manfaat, dan/atau dampak. 
Pemerintah berkewajiban melakukan evaluasi kinerja penyelenggaraan pemerintah daerah untuk mengetahui keberhasilan penyelenggaraan pemerintah daerah dalam memanfaatkan hak yang diperoleh oleh daerah dengan capaian keluaran dan hasil yang telah direncanakan (Arifianti et al., 2013). Berdasarkan PP No. 6 Tahun 2008 disebutkan bahwa salah satu evaluasi penyelenggaraan pemerintah daerah adalah berupa Evaluasi Penyelenggaraan Pemerintahan Daerah (EPPD). EPPD adalah suatu proses pengumpulan dan analisis data secara sistematis terhadap kinerja penyelenggaraan pemerintahan daerah, kemampuan penyelenggaraan otonomi daerah, dan kelengkapan aspek-aspek penyelenggaraan pemerintahan pada daerah yang baru dibentuk. Pemerintah dalam melakukan EPPD meliputi Evaluasi Kinerja Penyelenggaraan Pemerintah Daerah (EKPPD), Evaluasi Kemampuan Penyelenggaraan Otonomi Daerah (EKPOD) dan Evaluasi Daerah Otonomi Baru (EDOB). EKPPD dilakukan untuk menilai kinerja penyelenggaraan pemerintah daerah dalam upaya peningkatan kinerja berdasarkan prinsip kepemerintahan yang baik. Sumber utama yang digunakan untuk melakukan EKPPD adalah Laporan Penyelenggaraan Pemerintah Daerah (LPPD) dan laporan lain yang diterima oleh pemerintah, diantaranya laporan pertanggungjawaban pelaksanaan APBD, informasi keuangan daerah, laporan kinerja instansi pemerintah daerah dan lain-lain. EKPOD dilakukan untuk menilai kemampuan daerah dalam mencapai tujuan otonomi daerah yang meliputi peningkatan kesejahteraan masyarakat, kualitas pelayanan umum, dan kemampuan daya saing daerah. EDOB dilakukan untuk memantau perkembangan kelengkapan aspek-aspek penyelenggaraan pemerintahan daerah pada daerah yang baru dibentuk. EPPD dilaksanakan berdasarkan asas spesifik, obyektif, berkesinambungan, terukur, dapat diperbandingkan dan dapat dipertanggungjawabkan.

\section{Teori Agensi}

Teori agensi menurut pendapat Jensen dan Meckling (1976) merupakan hubungan keagenan sebagai kontrak di mana satu orang atau lebih (prinsipal) terlibat dengan orang lain (agen) untuk melakukan beberapa layanan atas nama mereka yang melibatkan pendelegasian beberapa wewenang pengambilan keputusan kepada agen. Dalam konteks pemerintahan dapat dikaitkan dengan hubungan rakyat dan pemerintah. Adanya kesepakatan atau kontrak yang ditetapkan oleh rakyat selaku prinsipal kepada pemerintah sebagai agen untuk menyediakan jasa yang diberikan kepada masyarakat. Adanya proses pendelegasian wewenang tersebut menimbulkan perbedaan kepentingan dari masing-masing peran yang mengakibatkan adanya sebuah konflik yang disebut sebagai agency conflict (Arifianti et al., 2013). Hal ini terkait dengan pendapat dari Jensen dan Meckling (1976) yang menyebutkan adanya permasalahan dalam agency theory, yaitu moral hazard bahwa permasalahan yang muncul jika agen tidak melaksanakan hal-hal yang telah disepakati bersama dalam kontrak dan adverse selection bahwa suatu keadaan dimana principal tidak dapat mengetahui apakah suatu keputusan yang 
diambil oleh agen benar-benar didasarkan atas informasi yang telah diperolehnya, atau terjadi sebagai sebuah kelalaian dalam tugas (Sutaryo dan Carolina 2014).

\section{Upper Echelons Theory}

Mengacu pada upper echelons theory yang dikembangkan oleh Hambrick dan Mason (1984), yaitu perusahaan/organisasi menjadi cerminan dari manajer puncaknya. Bagaimana perusahaan dalam menjalankan proses bisnisnya dan bagaimana cara mereka bersaing sangat dipengaruhi oleh karakteristik seorang pemimpin/manajer seperti kepribadian, demografi maupun latar belakang fungsional. Upper echelons theory menyebutkan bahwa manajemen memiliki pengaruh yang signifikan pada arah strategis dan melihatnya sebagai salah satu sumber daya strategis pada suatu perusahaan dan berhubungan erat dengan tingkat kinerja organisasi.

\section{Pengalaman Kepala Daerah dan Kinerja Penyelenggaraan Pemerintah Daerah}

De Angelo (1981) menunjukkan bahwa kompetensi dapat dicapai diantaranya dengan pengalaman dan pengetahuan. Pengalaman merupakan faktor yang mampu memberikan kontribusi positif pada peningkatan kinerja. Demikian halnya dengan masa jabatan yang didefinisikan sebagai lama seseorang dalam menduduki jabatan sebagai seorang pemimpin dalam sebuah organisasi. Manajer dengan pengalaman kerja yang lebih lama akan lebih baik dalam pengambilan keputusan, sehingga berpengaruh terhadap kinerja suatu organisasi. Hambrick dan Mason (1984) menjelaskan kompetensi dari seorang eksekutif terdiri dari usia, track fungsional, pengalaman karir, pendidikan, sosial ekonomi, posisi keuangan dan karakteristik kelompok. Hal ini didukung oleh penelitian Wiersema dan Bantel (1992) yang menggunakan masa jabatan manajemen puncak untuk memprediksi perubahan strategi perusahaan untuk peningkatan kinerja sebuah perusahaan.

Tujuan utama dari program kerja pemerintah daerah adalah memberikan pelayanan yang terbaik untuk masyarakat, sehingga diperlukan sebuah kepemimpinan yang mempunyai kemampuan dan ketrampilan yang memadai. Kepala daerah yang mempunyai masa jabatan lebih lama akan lebih baik dalam pengambilan keputusan/kebijakan dan diharapkan akan bisa meningkatkan kinerja penyelenggaraan pemerintah daerah. Kinerja yang meningkat dan semakin baik akan menumbuhkan kepercayaan yang lebih besar dari DPRD selaku prinsipal yang memberikan wewenang kepada kepala daerah untuk menjalankan tugasnya sebagai agen. Dalam penelitian ini, pengalaman diukur dengan menggunakan masa jabatan yang diartikan sebagai lama waktu seseorang menduduki jabatan dalam sebuah organisasi.

Berdasarkan uraian di atas, maka dapat dirumuskan hipotesis penelitian sebagai berikut. 
H1: Pengalaman kepala daerah berpengaruh positip terhadap kinerja penyelenggaraan pemerintah daerah.

\section{Kompetensi Kepala Daerah dan Kinerja Penyelenggaraan Pemerintah Daerah}

Hambrick dan Mason (1984) telah mencatat bahwa manajemen memiliki pengaruh signifikan pada arah strategis dan melihatnya sebagai salah satu sumber daya strategis pada suatu perusahaan. Untuk peningkatan kinerja penyelenggaraan pemerintah daerah dibutuhkan kompetensi kepala daerah. Kompetensi kepala daerah dapat diperoleh dari pengalaman dan latar belakang pendidikan dari kepala daerah tersebut. Melalui pendidikan seseorang mampu mengembangkan potensinya, sehingga dapat mewujudkan kepribadian, kecerdasan serta keterampilan yang diperlukan (Wiersema dan Bantel 1992). Pendidikan merupakan salah satu faktor yang paling berpengaruh dalam meningkatkan potensi ekonomi masyarakat, perusahaan dan negara (Magoutas et al., 2011). Semakin tinggi tingkat pendidikan yang ditempuh seseorang, maka semakin komplek pengetahuan dan keterampilan serta pengalaman yang dimilikinya. Hal tersebut diperkuat oleh penelitian Sebaa et al. (2009) yang menunjukkan bahwa pendidikan yang lebih tinggi akan mengarah ke peningkatan kinerja.

Bamber et al. (2010) menyatakan bahwa manajer yang berlatar pendidikan keuangan atau akuntansi mendukung anggaran yang lebih detail dan teliti, sehingga manajer yang memiliki latar belakang pendidikan keuangan atau akuntansi dapat mengembangkan dan menciptakan kinerja yang lebih tinggi. Balta et al. (2010), dalam penelitiannya, menunjukkan bahwa tingkat pendidikan dan latar belakang fungsional eksekutif mempengaruhi pelaporan keuangan dan desentralisasi hirarkis dalam pengambilan keputusan strategis. Ahmed dan Nicholls (1994) menyebutkan latar belakang pendidikan yang dimiliki oleh komisaris utama berpengaruh terhadap kinerja perusahaan. Seorang komisaris utama yang memiliki latar belakang pendidikan bisnis diharapkan akan meningkatkan kinerja perusahaan dibanding yang tidak berlatar belakang bisnis. Sutaryo dan Carolina (2014) menyatakan bahwa kepala daerah yang memiliki latar belakang pendidikan akuntansi atau ekonomi lebih cepat dalam menyusun APBD. Kepala daerah yang memiliki pengetahuan mengenai akuntansi/bisnis akan lebih memahami bagaimana proses pelaksanaan keuangan dan akuntansi, sehingga akan memudahkan dalam pelaksanaan dalam pengelolaan keuangan dan kinerja penyelenggaraan pemerintah daerah akan meningkat. Ketika kinerja penyelenggaraan daerah tersebut semakin baik, hal ini akan memberikan kepercayaan yang lebih besar dari prinsipal yaitu DPRD kepada pihak agen (kepala daerah).

Berdasarkan uraian di atas, maka dapat dirumuskan hipotesis penelitian sebagai berikut: 
H2: Kompetensi kepala daerah berpengaruh positif terhadap kinerja penyelenggaraan pemerintah daerah.

\section{Pengawasan Legislatif dan Kinerja Penyelenggaraan Pemerintah Daerah}

UU No. 32 Tahun 2004 tentang Pemerintah Daerah menyebutkan bahwa DPRD memiliki fungsi legislasi, penganggaran dan pengawasan. Peranan pengawasan yang dilakukan oleh DPRD merupakan sesuatu yang sangat penting untuk pelaksanaan jalannya tata pemerintahan (Winarna dan Murni 2007). Dengan meningkatnya tingkat pengawasan dari DPRD diharapkan dapat meningkatkan kinerja penyelenggaraan pemerintah daerah.

Kepala daerah yang mendapatkan dukungan dari partai politik akan dapat meminimalisir konflik keagenan dengan pihak DPRD sebagai prinsipal. Pengawasan yang semakin tinggi dari masyarakat yang diwakili oleh DPRD akan mempengaruhi kepala daerah dalam pengambilan keputusan dan kebijakan dengan lebih berhati-hati, sesuai dengan aturan perundang-undangan yang berlaku. Hal ini didukung penelitian Eriyanto (2007) yang menyatakan dukungan kursi yang dipunyai terutama parpol pendukung saat pencalonan, semakin besar dukungan parpol pengusung maka potensi konflik akan semakin kecil. Demikian sebaliknya, jika parpol pendukung semakin kecil maka potensi konflik semakin besar. Konflik yang terjadi antara pihak legislatif dan eksekutif akan memakan energi yang tidak sedikit, dan bisa jadi akan cukup mengganggu jalannya pemerintahan dan masyarakat yang akan menanggung dampaknya. Penelitian ini menggunakan pengawasan legislatif yang diproksikan dengan partai pengusung kepala daerah seperti yang dikemukakan oleh Arifianti et al. (2013).

Berdasarkan uraian di atas, maka dapat dirumuskan hipotesis penelitian sebagai berikut.

H3: Pengawasan legislatif berpengaruh positif terhadap kinerja penyelenggaraan pemerintah daerah.

\section{METODA PENELITIAN}

\section{Desain Penelitian}

Penelitian ini menggunakan jenis penelitian campuran (mixed methods research) yang menggabungkan antara metode kuantitatif dan metode kualitatif. Penelitian campuran menghasilkan fakta yang lebih komprehensif dalam meneliti masalah penelitian.

Penelitian ini menggunakan model sequential explanatory. Desain sequential explanatory merupakan penelitian kombinasi yang menggabungkan metode kuantitatif dan kualitatif secara berurutan. Pada tahap pertama, penelitian dilakukan dengan 
menggunakan metode kuantitatif dan pada tahap kedua dilakukan dengana metode kualitatif. Metode kuantitatif berperan untuk memperoleh data kuantitatif yang terukur yang dapat bersifat deskriptif, komparatif dan asosiatif. Metode kualitatif berperan untuk membuktikan, memperdalam, memperluas, memperlemah dan menggugurkan data kuantitatif yang telah diperoleh pada tahap awal. Untuk memperoleh data kualitatif, peneliti melakukan wawancara dengan nara sumber yang telah ditentukan, yang diharapkan bisa memberikan informasi yang dapat digunakan untuk melengkapi data kuantitatif.

Populasi dalam penelitian ini adalah LKPD pemerintah daerah kab/kota Jawa Timur. Total populasi adalah 152 kabupaten/kota dengan menggunakan (Laporan Keuangan Pemerintah Daerah (LKPD) Tahun Anggaran 2009 s/d 2012). Periode pengamatan dilakukan mulai tahun (2009 s/d 2013). Populasi penelitian tersaji dalam Tabel 3 berikut ini.

Tabel 3

\section{Data Penelitian}

\begin{tabular}{lc}
\hline \multicolumn{1}{c}{ Kriteria } & Jumlah \\
\hline Jumlah Kabupaten & 29 \\
Jumlah Kota & 9 \\
Total Sampel 1 Tahun & 38 \\
Total Sampel 4 Tahun & 152 \\
\hline Sumber: data diolah &
\end{tabular}

\section{Data dan Sumber Data}

Penelitian ini menggunakan data sekunder dan data primer. Jenis data dan sumber data yang digunakan dalam penelitian ini dijelaskan dalam Tabel 4.

Tabel 4

Data dan Sumber Data

\begin{tabular}{|c|c|c|}
\hline No & Data & Sumber Data \\
\hline 1 & $\begin{array}{l}\text { Pemerintah Kabupaten/kota tahun } 2009 \text { s/d } 2012 \\
\text { yang menerbitkan LKPD dan telah diaudit oleh BPK, } \\
\text { menyajikan data dan informasi yang dibutuhkan } \\
\text { dalam penelitian. }\end{array}$ & $\begin{array}{l}\text { Soft copy LKPD kab/kota provinsi } \\
\text { Jatim dari BPK RI Perwakilan } \\
\text { Jatim }\end{array}$ \\
\hline 2 & $\begin{array}{l}\text { Skor Kinerja Penyelenggaraan Pemerintah Daerah } \\
\text { tahun } 2010 \text { sampai dengan } 2013 \text {. }\end{array}$ & Website Kemendagri \\
\hline 3 & $\begin{array}{l}\text { Pemerintah daerah kabupaten/kota yang mempunyai } \\
\text { website tetapi menyajikan data profil kepala daerah } \\
\text { dan legislatif daerah. }\end{array}$ & $\begin{array}{l}\text { Buku profil kepala daerah } \\
\text { Kemendagri dan } \\
\text { pemerintah daerah }\end{array}$ \\
\hline 4 & Data Indeks Pembangunan Manusia (IPM) & Website BPS Provinsi Jawa Timur \\
\hline
\end{tabular}

\section{Definisi Operasional dan Pengukuran Variabel}

Penelitian ini menggunakan variabel dependen dan independen, serta ditambah dengan variabel kontrol. Adapun definisi dan pengukuran masing-masing variabel akan dijelaskan dalam Tabel 5 (Lampiran) berikut ini. 


\section{Analisis Data}

Analisis data pada penelitian ini menggunakan analisis regresi berganda, dan sebelumnya dipaparkan statistik deskriptif dalam bentuk nilai minimum dan maksimum setiap variabel. Hipotesis diterima jika nilai signifikansi di bawah 0,05.

\section{ANALISIS DAN PEMBAHASAN}

\section{Statistik Deskriptif}

Hasil statistik deskriptif yang dihasilkan pada penelitian ini disajikan dalam Tabel 6 berikut ini.

Tabel 6

Deskripsi Data Penelitian

\begin{tabular}{lccc}
\hline \multicolumn{1}{c}{ Variabel } & Minimum & Maximum & Mean \\
\hline Pengalaman (X1) & 1 & 6 & \\
Kompetensi (X2) & 0 & 1 & 0,33 \\
Pengawasan (X3) & 1 & 11 & 2,53 \\
Anggota DPRD & 25 & 50 & 44,11 \\
LEV & 0,00 & 0,0333636196 & 0,002883637647 \\
SPI & 3 & 19 & 9.43 \\
KTU & 1.00 & 20.00 & 9.1053 \\
WAS & 59.00 & 78.00 & 70.9013 \\
KNJ (Y) & 2.0022 & 3.4787 & 2.956872 \\
ASET & 17386741568,44 & 35358824156594,80 & 3394741182269,26 \\
PAD & 25567881123,83 & 1886514301580,72 & 140214943705,86 \\
\hline
\end{tabular}

Keterangan :

Pengalaman = Masa jabatan kepala daerah; Kompetensi $=$ Latar belakang pendidikan ekonomi bisnis/akuntansi; Pengawasan $=$ Partai politik pengusung kepala daerah; Aset $=$ Jumlah aset; PAD = Jumlah PAD; DPRD = Jumlah anggota DPRD; LEV = Leverage $;$ SPI = Kelemahan SPI; KTU = Ketidakpatuhan terhadap peraturan perundang-undangan; WAS = Pengawasan Masyarakat Sumber: Data diolah

Sebelum dilakukan pengujian hipotesis, berdasarkan uji asumsi klasik (normalitas, multikolinieritas, autokorelasi, dan heteroskedastisitas), diperoleh bahwa dalam model yang digunakan tidak terjadi penyimpangan asumsi klasik, artinya model regresi pada penelitian ini dapat digunakan sebagai dasar analisis. Alat analisis yang digunakan dalam penelitian ini adalah model regresi linier berganda (multiple regression) untuk mengetahui pengaruh variabel independen terhadap variabel dependen. Hasil persamaan regresi yang digunakan dalam penelitian ini dapat dijelaskan dalam Tabel 7 sebagai berikut. 
Tabel 7

Hasil Uji Regresi Linier Berganda

\begin{tabular}{lcccl}
\hline \multicolumn{1}{c}{ Variabel } & $\begin{array}{c}\text { Koefisien } \\
\text { Regresi }\end{array}$ & thitung & Signifikansi & Kesimpulan \\
\hline (Constant) & 1,310 & & & \\
Pengalaman (X1) & $-0,008$ & $-0,648$ & 0,518 & Ha tidak didukung \\
Kompetensi (X2) & 0,015 & 0,474 & 0,636 & Ha tidak didukung \\
Pengawasan (X3) & 0,006 & 0,834 & 0,406 & Ha tidak didukung \\
ASET & 0,047 & 2,246 & $0,026^{*}$ & \\
PAD & $-0,003$ & $-0,127$ & 0,899 & \\
DPRD & $-0,001$ & $-0,568$ & 0,571 & \\
LEV & 5,897 & 2,056 & $0,042^{*}$ & \\
SPI & $-0,010$ & $-2,231$ & $0,027^{*}$ & \\
KTU & $-0,007$ & $-2,045$ & $0,043^{*}$ & \\
WAS & 0,009 & 2,175 & $0,031^{*}$ & \\
\hline F hitung & 3,313 & & & \\
F Prob & 0,001 & & & \\
R $^{2}$ & 0,201 & & & \\
Adjusted $\mathrm{R}^{2}$ & 0,140 & & & \\
\end{tabular}

Keterangan :

Pengalaman = Masa jabatan kepala daerah; Kompetensi $=$ Latar belakang pendidikan ekonomi bisnis/akuntansi; Pengawasan $=$ Partai politik pengusung kepala daerah; Aset $=$ Jumlah aset; PAD = Jumlah PAD; DPRD = Jumlah anggota DPRD; LEV = Leverage $;$ SPI = Kelemahan SPI; KTU = Ketidakpatuhan terhadap peraturan perundang-undangan; WAS = Pengawasan masyarakat *Signifikan dalam level 5\%

Sumber: Data diolah

\section{Pengujian Hipotesis}

Hasil analisis regresi berganda diperoleh nilai Adjusted $R^{2}$ sebesar 0,140 atau 14 persen. Hasil ini mengindikasikan bahwa terdapat 5 variabel yang mempengaruhi kinerja pemda dalam penelitian ini yang terdiri aset, leverage, jumlah kasus SPI, ketidakpatuhan terhadap ketentuan perundang-undangan dan IPM mampu menjelaskan variabilitas dependen kinerja penyelenggaraan pemda sebesar 14 persen. Sementara, sisanya 86 persen dijelaskan oleh variabel lain yang tidak ikut terobservasi.

Berdasarkan hasil perhitungan menunjukkan bahwa probability value dari model regresi variabel dependen kinerja penyelenggaraan pemda yang digunakan dalam penelitian lebih kecil dari tingkat signifikansi penelitian 1 persen, yaitu sebesar 0,001. Hasil ini mengindikasikan bahwa model regresi yang digunakan dalam penelitian ini layak (fit) untuk digunakan sebagai model regresi pengujian hipotesis. Kesimpulannya ada pengaruh yang signifikan dari pengalaman, kompetensi, pengawasan legislatif, aset, jumlah anggota DPRD, PAD, leverage, jumlah kasus SPI, jumlah kasus ketidakpatuhan terhadap ketentuan perundang-undangan dan pengawasan masyarakat terhadap kinerja penyelenggaraan pemda secara simultan. 


\section{Pengaruh Pengalaman Kepala Daerah terhadap Kinerja Penyelenggaraan Pemerintah Daerah Kabupaten/Kota Provinsi Jawa Timur.}

Mengacu pada upper echelons theory yang dikembangkan oleh Hambrick dan Mason (1984), perusahaan/organisasi menjadi cerminan dari manajer puncaknya. Bagaimana perusahaan dalam bersaing di pasar sangat dipengaruhi oleh karakteristik seorang pemimpin seperti kepribadian, demografi maupun latar belakang fungsional. Manajemen memiliki pengaruh yang besar pada arah dan tujuan strategis perusahaan dan menjadikan hal tersebut sebagai sumber daya berpotensi yang dimiliki oleh perusahaan. Demikian halnya kepala daerah untuk melaksanakan pemerintahanya dibutuhkan seorang figur yang mempunyai kompetensi dan pengalaman kerja yang baik untuk menghasilkan tujuan strategis pemerintah. Dalam penelitian ini pengalaman kerja diukur dengan masa jabatan kepala daerah. Berdasarkan hasil analisis, koefisien parameter pengaruh antara variabel pengalaman terhadap kinerja penyelenggaraan pemerintah daerah adalah sebesar $-0,008$ dengan signifikansi 0,518 $>0.05$. Hasil analisis menunjukkan bahwa pengalaman berpengaruh negatif dan tidak signifikan terhadap kinerja penyelenggaraan pemerintah daerah yang berarti masa jabatan kepala daerah tidak mempengaruhi kinerja penyelenggaraan pemerintah daerah kabupaten/kota Jawa Timur. Penelitian ini kontradiktif dengan penelitian Wiersema dan Bantel (1992) yang menyebutkan masa jabatan masa jabatan manajemen puncak untuk memprediksi perubahan strategi perusahaan untuk peningkatan kinerja sebuah perusahaan.

Berdasarkan hasil wawancara dengan kepala daerah kabupaten/kota di Jawa Timur disebutkan bahwa pimpinan dengan pengalaman kerja yang lebih lama dapat lebih baik dalam pengambilan keputusan/kebijakan, sehingga berpengaruh terhadap kinerja penyelenggaraan pemerintah daerah. Pengambilan keputusan tersebut menentukan tingkat keberhasilan dalam pencapaian tujuan yang telah ditetapkan. Semakin lama seorang pimpinan dalam jabatan tersebut akan menjadikan peningkatan pengalaman. Kepala daerah yang berpengalaman dalam hal manajemen akan menunjukkan tingkat kreatifitas dan inovasi yang baik, lebih berhati-hati dalam mengambil sebuah keputusan, sehingga tujuan dari pelaksanaan pemerintahan yaitu penyediaan pelayanan publik bisa optimal dan kinerja penyelenggaraan pemerintah daerah menjadi meningkat. Dengan masa jabatan/pengalaman kerja yang lebih lama memungkinkan kepala daerah untuk melakukan adaptasi terhadap perubahanperubahan yang terjadi, terciptanya proses pembelajaran dan perbaikan-perbaikan terhadap keputusan atau kebijakan yang diambil demi penyempurnaan pelaksanaan kegiatan dimasa yang akan datang.

Walaupun secara teori dan hasil wawancara menunjukkan hasil yang positif terhadap pengalaman kerja (masa jabatan), namun hasil analisis berdasarkan koefisien parameternya menunjukkan arah yang berlawanan yaitu negatif dan tidak signifikan. Hal ini dimungkinkan jabatan lebih lama bisa menimbulkan perilaku oportunistik. Pihak eksekutif memiliki keunggulan pada penguasaan informasi mengenai posisi 
keuangan dan posisi operasi sebuah entitas dibanding pihak legislatif (masyarakat). Adanya ketidakseimbangan masalah informasi tersebut memberikan kesempatan bagi para kepala daerah untuk meningkatkan kesejahteraan pribadinya atau untuk golongan tertentu.

Perilaku oportunistik ini pernah dilakukan oleh kepala daerah Kabupaten Kutai Kartanegara yang bernama Syaukani H.R. yang menjabat sebagai bupati tahun 19992004 dan diangkat kembali periode 2005-2010. Pada tahun 2006, KPK telah menetapkan Syaukani sebagai tersangka dalam kasus korupsi dengan menyalahgunakan dana perangsang pungutan sumber daya alam (migas), dana studi kelayakan bandara Kutai, dana pembangunan bandara Kutai, dan penyalahgunaan dana pos anggaran kesejahteraan masyarakat (Mon 2007). Hal yang sama terjadi pada mantan Bupati Lumajang, mantan orang kuat yang pernah menjabat Bupati Lumajang selama 2 periode 1998-2003 dan 2003-2008, pada jabatan keduanya berurusan dengan kasus hukum. Achmad Fauzi (mantan Bupati Lumajang) melakukan korupsi dana proyek Kerjasama Operasional Penambangan Bahan Galian C berupa pasir di Gunung Semeru di Kabupaten Lumajang yang merugikan negara Rp5,2 miliar (Priyasidharta 2011).

\section{Pengaruh Kompetensi Kepala Daerah terhadap Kinerja Penyelenggaraan Pemerintah Daerah Kabupaten/Kota Provinsi Jawa Timur.}

Kepala daerah mempunyai peranan yang penting dalam pengambilan keputusan dan kebijakan penyelenggaraan pemerintah daerah. Kepala daerah mempunyai kewajiban untuk melaksanakan dan mempertanggungjawabkan pengelolaan keuangan daerah. Oleh karena itu, pemerintah daerah membutuhkan kepala daerah yang kompeten dalam menjalankan tata pemerintahan. Menurut Hambrick dan Mason (1984), eksekutif yang memiliki level pendidikan yang lebih tinggi memiliki nilai kognitif yang lebih baik. Hasil analisis menunjukkan hal yang berbeda dilihat dari hasil koefisien parameter pengaruh antara variabel kompetensi kepala daerah terhadap kinerja penyelenggaraan pemerintah daerah adalah sebesar 0,015 dengan signifikansi $0,636>0,05$. Hasil tersebut menunjukkan bahwa kompetensi kepala daerah berpengaruh positif dan tidak signifikan terhadap kinerja penyelenggaraan pemerintah daerah yang berarti kompetensi kepala daerah yang ditunjukkan menggunakan latar belakang pendidikan ekonomi bisnis/akuntansi kepala daerah belum bisa memberikan pengaruh yang signifikan terhadap kinerja penyelenggaraan pemerintah daerah kabupaten/kota Jawa Timur. Hal ini mengindikasikan bahwa pemda merupakan organisasi yang bergerak dalam lingkungan yang komplek dan yang dihadapi tidak hanya dari segi keuangan saja. Masih terdapat bidang lain yang perlu mendapat perhatian agar tercapainya pemenuhan pelayanan publik. Hasil ini sejalan dengan penelitian Haniffa dan Cooke (2005) yang menyebutkan bahwa tidak adanya pengaruh latar belakang pendidikan bisnis/akuntansi disebabkan dalam penelitian hanya mendefinisikan latar belakang secara spesifik pada bisnis dan keuangan. 
Hasil penelitian ini didukung berdasarkan hasil wawancara dengan kepala daerah disebutkan bahwa latar belakang pendidikan seorang pemimpin merupakan hal yang penting, semakin tinggi level pendidikan yang dimiliki secara normative akan membawa ke arah yang lebih baik. Kepala daerah yang memiliki pengalaman dibidang akuntansi/bisnis lebih memahami pengelolaan keuangan daerah. Namun, kepala daerah juga dituntut ahli dalam berbagai bidang. Banyak permasalahan yang harus dihadapi, sehingga dibutuhkan keseimbangan dalam hal pengalaman/keahlian dan kompetensi (latar belakang pendidikan). Keseimbangan tersebut diharapkan mampu membawa pelaksanaan tata pemerintahan daerah lebih efektif, efisien dan dapat dipertanggungjawabkan.

Hasil penelitian ini kontradiktif dengan penelitian yang dilakukan oleh Bamber et al. (2010) yang menunjukkan bahwa manajer yang memiliki latar belakang pendidikan keuangan atau akuntansi dapat mengembangkan dan menciptakan kinerja yang lebih tinggi. Hasil penelitian ini juga kontradiktif dengan Ahmed dan Nicholls (1994) menyebutkan latar belakang pendidikan yang dimiliki oleh komisaris utama berpengaruh terhadap kinerja perusahaan. Hasil penelitian ini juga kontradiktif dengan penelitian Sutaryo dan Carolina (2014) yang menunjukkan bahwa kepala daerah yang memiliki latar belakang pendidikan akuntansi atau ekonomi lebih cepat dalam menyusun APBD.

\section{Pengaruh Pengawasan Legislatif terhadap Kinerja Penyelenggaraan Pemerintah Daerah Kabupaten/Kota Provinsi Jawa Timur.}

Dari hasil koefisien parameter pengaruh antara variabel partai pengusung kepala daerah terhadap kinerja penyelenggaraan pemerintah daerah adalah sebesar 0,006 dengan signifikansi 0,406 > 0,05. Hasil analisis menunjukkan bahwa partai pengusung kepala daerah berpengaruh positif dan tidak signifikan terhadap kinerja penyelenggaraan pemerintah daerah. Artinya bahwa partai pengusung kepala daerah belum bisa memberikan dampak yang signifikan terhadap kinerja penyelenggaraan pemda kabupaten/kota Jawa Timur. Hal ini mengindikasikan bahwa dimungkinkan dukungan parpol pengusung kepala daerah mempunyai pengaruh hanya pada saat pencalonan menjadi kepala daerah. Pada saat perjalanan pemerintahan selanjutnya, kompetensi seorang kepala daerah dalam menjaga hubungan keharmonisan dengan pihak legislatif akan lebih berpengaruh dibanding dengan jumlah parpol pengusung saat awal pencalonan.

Hasil yang tidak signifikan itu dimungkinkan peran DPRD dalam melakukan fungsinya belum maksimal/optimal dan belum bekerja secara profesional. Penyebab belum optimalnya fungsi pengawasan DPRD karena sistem partai yang terpusat membuat anggota DPRD menjadi lebih memperjuangkan kepentingan partainya, sehingga dalam pengambilan keputusan belum bisa melepaskan diri dari kepentingan kelompoknya (Arifianti et al., 2013). 
Hasil analisis tersebut didukung berdasarkan hasil wawancara dengan kepala daerah disebutkan bahwa dukungan dari partai politik pengusung kepala daerah diperlukan guna mendukung kesuksesan pimpinan dalam menjalankan tata pemerintahan. Semakin banyak parpol yang mendukung kepala daerah secara tidak langsung menunjukkan banyaknya dukungan dan partisipasi masyarakat terhadap pemerintahan. Namun, hal yang lebih utama adalah bagaimana kepala daerah bisa berkomunikasi politik dengan pihak legislatif. Meskipun kepala daerah saat pencalonan berangkat dari parpol minoritas, tetapi saat menjalankan pemerintahannya pimpinan (kepala daerah) bisa menunjukkan potensinya. Hal tersebut akan memberikan kepercayaan kepada DPRD, sehingga visi misi program dan kegiatan yang di emban dapat dilaksanakan dengan baik.

Hasil penelitian ini kontradiktif dengan penelitian yang dilakukan oleh Eriyanto (2007) yang menyatakan dukungan kursi yang dipunyai terutama parpol pendukung saat pencalonan, semakin besar dukungan parpol pengusung kepala daerah maka potensi konflik akan semakin kecil demikian sebaliknya jika parpol pendukung kepala daerah semakin kecil maka potensi konflik semakin besar. Hasil penelitian ini juga kontradiktif dengan penelitian Sutaryo dan Carolina (2014) yang menyebutkan bahwa komposisi DPRD berpengaruh terhadap ketepatan waktu penetapan APBD.

\section{Pengaruh Ukuran (Size) terhadap Kinerja Penyelenggaraan Pemerintah Daerah Kabupaten/Kota Provinsi Jawa Timur.}

Dalam penelitian ini menggunakan 2 proksi pengukuran ukuran (size) yaitu jumlah aset pemda dan jumlah anggota DPRD. Pengkuran pertama menggunakan jumlah aset daerah. Hasil analisis menunjukkan bahwa aset daerah berpengaruh positif dan signifikan terhadap kinerja penyelenggaraan pemerintah daerah yang berarti semakin banyak aset daerah akan menaikkan kinerja penyelenggaraan pemerintah daerah kabupaten/kota Jawa Timur. Hal ini mengindikasikan pemerintah daerah sudah bisa memaksimalkan aset secara efektif untuk meningkatkan kinerjanya. Pemda dengan ukuran yang besar memiliki tekanan yang besar untuk melakukan pelayanan yang baik kepada masyarakat serta pengungkapan atas laporan kinerjanya. Selain itu, dengan ukuran aset yang besar akan memberikan kemudahan kegiatan operasional yang kemudian juga akan mempermudah dalam pemberian pelayanan masyarakat yang memadai.

Hasil penelitian ini sejalan dengan penelitian yang dilakukan oleh beberapa peneliti terdahulu antara lain Haniffa dan Cooke (2005); Agiomirgianakis et al. (2006); Patrick (2007); Papadogonas (2007); Liargovas dan Skandalis (2010); Pervan dan Visic (2012); Almajali et al. (2012); Omondi dan Muturi (2013); Mustikarini dan Fitriasari (2012); Agustinus et al. (2008); dan Hasibuan (2009) yang menyebutkan ukuran organisasi mempunyai pengaruh yang signifikan terhadap kinerja organisasi.

Pengukuran yang kedua menggunakan jumlah anggota DPRD. Hasil analisis menunjukkan bahwa jumlah anggota DPRD tidak berpengaruh terhadap kinerja 
penyelenggaraan pemerintah daerah yang berarti jumlah anggota DPRD pemda tidak mempengaruhi kinerja penyelenggaraan pemerintah daerah kabupaten/kota provinsi Jawa Timur.

Hasil analisis terhadap ukuran jumlah aset daerah dengan jumlah anggota DPRD menunjukkan perbedaan. Perbedaan ini mungkin disebabkan pada fokus pengukuran. Aset daerah dihubungkan dengan manfaat yang bisa diberikan kepada masyarakat, sehingga dengan besarnya aset akan meningkatkan tingkat pelayanan jasa kepada masyarakat. Jumlah anggota DPRD ukurannya didasarkan pada jumlah penduduk kabupaten/kota yang bersangkutan dengan sejumlah ketentuan yang disyaratkan dalam peraturan perundang-undangan. Hal tersebut dimungkinkan banyak sedikitnya sumber daya manusia belum bisa menjamin secara penuh pada peningkatan kinerja penyelenggaraan pemerintah daerah.

\section{Pengaruh Tingkat Kemakmuran terhadap Kinerja Penyelenggaraan Pemerintah Daerah Kabupaten/Kota Provinsi Jawa Timur.}

Hasil analisis menunjukkan bahwa PAD berpengaruh negatif tidak signifikan terhadap kinerja penyelenggaraan pemerintah daerah yang berarti peran PAD dalam meningkatkan kinerja pemerintah daerah belum dapat berfungsi sebagaimana mestinya. Kondisi ini dimungkinkan karena masih besarnya porsi transfer dana dari pusat (besarnya tingkat ketergantungan pemda terhadap pemerintah pusat) menyebabkan pemda dalam membiayai penyelenggaraan pemerintahannya masih mengandalkan dana transfer dari pusat tersebut.

Hasil penelitian ini kontradiksi dengan beberapa penelitian terdahulu, yaitu Lasward et al. (2005); Sularso dan Restianto (2011); Mustikarini dan Fitriasari (2012); Sudarsana dan Rahardjo (2013); Setyaningrum dan Syafitri (2012); Simanulang (2013); Florida (2006); dan Julitawati et al. (2012) yang menyebutkan bahwa tingkat kekayaan (PAD) berpengaruh signifikan terhadap kinerja organisasi (pemda).

\section{Pengaruh Leverage terhadap Kinerja Penyelenggaraan Pemerintah Daerah Kabupaten/Kota Provinsi Jawa Timur.}

Hasil analisis menunjukkan bahwa leverage berpengaruh terhadap kinerja penyelenggaraan pemerintah daerah kabupaten/kota provinsi Jawa Timur. Hal ini mengindikasikan bahwa leverage yang diproksikan dengan perbandingan jumlah utang dengan ekuitas pemerintah daerah, semakin tinggi menunjukkan pemda dapat memberikan kepercayaan dan keyakinan kepada investor bahwa pemda dapat memaksimalkan penggunaan modal eksternal dalam mengembangkan pemda tersebut dengan adanya peningkatan kinerja penyelenggaraan pemerintah daerah. Hasil penelitian ini konsisten dengan penelitian Lasward et al. (2005); Almajali et al. (2012); Liargovas dan Skandalis (2010); Gwey dan Karanja (2014); Bhunia (2010); Pervan dan Visic (2012); Papadogonas (2007); dan Ludjianto et al. (2014) yang menyatakan bahwa Debt to Equity Ratio (DER) berpengaruh signifikan terhadap Return On Investment (ROI). Hasil penelitian ini kontradiktif dengan (Khalifa dan Shafii 2013) 
yang hasilnya penelitiannya menunjukkan tidak ada hubungan antara DER dengan ROA perusahaan.

\section{Pengaruh Kelemahan Sistem Pengendalian Internal (SPI) terhadap Kinerja Penyelenggaraan Pemerintah Daerah Kabupaten/Kota Provinsi Jawa Timur.}

Hasil analisis menunjukkan bahwa jumlah kasus SPI berpengaruh negatif terhadap kinerja penyelenggaraan pemerintah daerah pada pemerintah daerah kabupaten/kota provinsi Jawa Timur. Hasil ini menunjukkan pemerintah daerah dengan kasus jumlah kasus SPI yang banyak akan memberikan dampak pada rendahnya kinerja penyelenggaraan pemerintah daerah kabupaten/kota provinsi Jawa Timur. Hasil penelitian ini sesuai dengan penelitian yang dilakukan oleh Arifianti et al. (2013) yang menyatakan bahwa dengan adanya SPI yang efektif, maka kinerja yang dihasilkan akan semakin tinggi.

Auditor membantu entitas untuk bertanggungjawab kepada masyarakat melalui peningkatan pengendalian intern yang efisien dan kinerja keuangan. Pelaksanaan audit sebagai fungsi pengawasan mempunyai pengaruh yang besar terhadap integritas laporan keuangan yang bertujuan meningkatkan kualitas tata kelola perusahaan dan mencegah kegagalan organisasi (Okpala 2012). Audit laporan keuangan merupakan alat yang penting untuk mengurangi asimetri dan meningkatkan kinerja keuangan perusahaan (Farouk dan Hassan 2014). Partisipasi pimpinan dalam penyusunan anggaran, dan adanya kejelasan sasaran anggaran yang akan dilaksanakan, diharapkan dapat berpengaruh terhadap kinerja dengan adanya sistem pengendalian dan pengawasan internal yang efektif (Arifianti et al., 2013).

\section{Pengaruh Kepatuhan terhadap Ketentuan Perundang-Undangan terhadap Kinerja Penyelenggaraan Pemerintah Daerah Kabupaten/Kota Provinsi Jawa Timur}

Hasil analisis menunjukkan bahwa ketidakpatuhan terhadap ketentuan perundang-undangan berpengaruh negatif terhadap kinerja penyelenggaraan pemerintah daerah kabupaten/kota Provinsi Jawa Timur. Hasil penelitian ini sesuai dengan penelitian sebelumnya, yaitu ketidakpatuhan pemerintah daerah terhadap ketentuan perundang-undangan berpengaruh negatif signifikan terhadap kinerja penyelenggaraan pemerintahan daerah. Semakin banyak temuan audit, maka pengelolaan keuangan pemerintah daerah tersebut kurang baik, yang pada akhirnya akan berpengaruh terhadap buruknya kinerja dari pemerintah daerah tersebut (Mustikarini dan Fitriasari 2012). Kondisi ini memperlihatkan bahwa keberhasilan penerapan akuntabilitas kinerja instansi pemerintah daerah banyak dipengaruhi oleh ketaatan pada ketentuan perundang-undangan (Arifianti et al., 2013). Praktik kepatuhan yang baik akan selalu mendukung fungsi efisien dan efektif dari suatu organisasi, sehingga dengan kepatuhan yang baik yang merupakan bagian dari manajemen yang baik, akan menghasilkan kinerja yang baik. 


\section{Pengaruh Pengawasan Masyarakat terhadap Kinerja Penyelenggaraan Pemerintah Daerah Kabupaten/Kota Provinsi Jawa Timur.}

Pengawasan masyarakat dalam penelitian ini diproksikan dengan menggunakan IPM. Berdasarkan hasil analisis menunjukkan bahwa IPM pemda mempengaruhi kinerja penyelenggaraan pemerintah daerah kabupaten/kota Provinsi Jawa Timur. Hal ini mengindikasikan bahwa daerah dengan IPM yang baik memberikan dampak yang baik pada kinerja penyelenggaraan pemerintah daerah. Hasil penelitian ini sesuai dengan penelitian sebelumnya, yaitu IPM memberikan pengaruh positif terhadap kinerja penyelenggaraan pemerintahan daerah. Artinya, ketika kualitas pembangunan manusia baik maka kinerja juga akan meningkat (Amaliah 2004). Ini terjadi karena penduduk di daerah tersebut akan lebih mudah dalam menerima berbagai informasi maupun teknologi yang ada. Penduduk di daerah tersebut akan menjadi lebih produktif dalam mengelola sumber-sumber potensial yang dapat mendorong pertumbuhan daerahnya. Sumber daya manusia (SDM) merupakan motor penggerak tumbuhnya perekonomian suatu wilayah (Arifianti et al., 2013). Partisipasi masyarakat sangat penting dalam pemerintahan karena pada dasarnya bentuk kebijakan otonomi dan desentralisasi harus tetap mengedepankan aspirasi dan kepentingan masyarakat. Jika partisipasi rakyat di daerah tinggi maka proses terciptanya otonomi dan desentralisasi akan terlaksana dengan lancar dan baik.

\section{SIMPULAN, KETERBATASAN DAN SARAN}

Penelitian ini dilakukan untuk menguji variabel profil kepala daerah yang terdiri dari pengalaman kerja, kompetensi dan pengawasan legislatif terhadap kinerja penyelenggaraan pemerintah daerah kabupaten/kota di Provinsi Jawa Timur. Faktor yang diduga berpengaruh dalam penelitian ini digunakan sebagai variabel kontrol antara lain ukuran (size), leverage, kualitas laporan keuangan, dan pengawasan masyarakat.

Hasil analisis menunjukkan bahwa pengalaman, kompetensi, pengawasan legislatif, PAD, jumlah ukuran (size), leverage, kualitas laporan keuangan dan pengawasan masyarakat secara simultan berpengaruh signifikan terhadap kinerja penyelenggaraan pemerintah daerah kabupaten/kota Provinsi Jawa Timur. Secara parsial variabel kontrol jumlah aset, leverage, jumlah kasus SPI, ketidakpatuhan terhadap ketentuan perundang-undangan, dan pengawasan masyarakat berpengaruh signifikan terhadap kinerja penyelenggaraan pemda kabupaten/kota di provinsi Jawa Timur.

Variabel independen profil kepala daerah tidak terbukti dapat mempengaruhi kinerja penyelenggaraan pemerintah daerah. Hal ini disebabkan pemda bergerak dalam lingkungan yang sangat kompleks dan variatif. Banyak hal yang mempengaruhinya baik itu dari segi ekonomi, politik, kultural maupun demografi. 
Untuk itu, dalam menjalankan tata pemerintahan diperlukan keseimbangan hal pengalaman dan kompetensi dari kepala daerah.

Penelitian terdahulu yang menggunakan metode penelitian kuantitatif terhenti setelah pengujian hipotesis terbukti atau tidak terbukti. Namun dengan menggunakan mixed methods research, penelitian ini tidak berhenti pada pengujian hipotesis, tetapi dilanjutkan lagi dengan menggunakan metode kualitatif untuk menghasilkan kesimpulan yang lebih komprehensif, valid, reliabel, dan obyektif.

Dalam penelitian ini, terdapat beberapa keterbatasan yang dapat mempengaruhi hasil penelitian. Pertama, rendahnya nilai adjusted $R^{2}$ dari model yang di uji dalam penelitian ini menunjukkan bahwa banyak variabel lain yang tidak digunakan dalam penelitian ini mempunyai pengaruh yang besar. Kedua, proksi yang digunakan untuk mengukur variabel dependen menggunakan skor peringkat kinerja pemerintah daerah yang sifatnya mengukur kinerja pemerintah daerah yang cakupanya terlalu luas.Berdasarkan beberapa keterbatasan tersebut, maka peneliti mengajukan beberapa saran-saran untuk penelitian selanjutnya. Pertama, penelitian yang akan datang sebaiknya mempertimbangkan untuk menggunakan variabel lainnya di luar variabel yang digunakan dalam penelitian ini. Misalnya, penelitian selanjutnya menguji pengaruh interaksi latar belakang pendidikan kepala daerah dengan pengalaman terhadap kinerja penyelenggaraan pemda. Kedua, penelitian yang akan datang sebaiknya tetap menggunakan metode penelitian mixed methods research untuk menjawab gap yang terjadi pada peneliti sebelumnya dan menggunakan sampel yang lebih luas, tidak hanya mencakup satu provinsi saja agar hasil yang diperoleh lebih dapat digeneralisir. Ketiga, penelitian yang akan datang sebaiknya menggunakan alternatif pengukuran kinerja yang lain dalam mengukur kinerja pemda, misalnya LAKIP (Laporan Akuntabilitas Kinerja Instansi Pemerintah Daerah) tiap-tiap kabupaten/kota atau rasio keuangan seperti rasio kemandirian, rasio ketergantungan dan rasio derajat desentralisasi.

\section{DAFTAR PUSTAKA}

Agiomirgianakis, G. M., F. Voulgaris, dan T. Papadogonas. 2006. "Financial factors affecting profitability and employment growth: The case of Greek manufacturing". International Journal Financial Management 1(2/3): 235245.

Agustinus., Prasetyantoko, dan P. Rachmadi. 2008. "Determinants of corporate performance of listed companies in Indonesia". Munich Personal Repec Archive (MPRA) Paper. Atma Jaya Catholic University.

Ahmed, K., dan D. Nicholls. 1994. T'he impact of non-financial company characteristics on mandatory disclosure compliance in developing countries: The case of Bangladesh". The International Journal of Accounting 29: 62-77. 
Ali, A. 2014. "Surabaya kota paling banyak merugikan negara”. Realita. Diakses 27 Juli 2015. Tersedia di http://www.realita.co/index.php?news=Surabaya,-KotaPaling-Banyak-Merugikan-Negara

Almajali, A. Y., S. A. Alamro, dan Y. Z. Al-Soub. 2012. "Factor affecting the financial performance of Jordanian insurance companies listed at Amman Stock Exchange". Journal of Management Research 4(2): 266-289.

Amaliah, I. 2004. "Pengaruh pembangunan manusia terhadap kinerja ekonomi dati II di Jawa Barat 1999-2003”. Jurnal Mimbar Dikti 22(2): 213-233.

Arifianti, H., Payamta, dan Sutaryo. 2013. "Pengaruh pemeriksaan dan pengawasan keuangan daerah terhadap kinerja penyelenggaraan pemerintahan daerah (Studi empiris pada pemerintah kabupaten/kota di Indonesia)". Simposium Nasional Akuntansi XVI. Manado.

Balta, M. E., A. Woods, dan K. Dickson. 2010. "The influence of boards of directors' characteristics on strategic decision-making: Evidence from Greek companies". The Journal of Applied Business Research 26(3): 57-68.

Bamber, L. S., J. Jiang, dan I. Y. Wang. 2010. "What's my style? The influence of top managers on voluntary corporate financial disclosure". The Accounting Review 85(4): 1131-1162.

Batafor, G. G. 2011. "Evaluasi kinerja keuangan dan tingkat kesejahteraan masyarakat Kabupaten Lembata - Provinsi NTT”. Tesis. Universitas Udayana Denpasar.

Bhunia, A. 2010. "Financial performance of Indian pharmaceutical industry - a case study". Asian Journal of Management Research 427-451.

DeAngelo, L. E. 1981. “Auditor Size and Audit Quality”. Journal of Accounting and Economics 3(3): 183-199.

DeBruijn, H. 2002. "Performance measurement in the public sector: Strategies to cope with the risks of performance measurement". International Journal of Public Sector Management 15(7): 578-594.

Destyan, S. 2013. "Penyerapan APBD Trenggalek baru 50 persen”. Antara Jatim. $\begin{array}{llllll}\text { Diakses } & 27 & \text { Juli } & 2015 . & \text { Tersedia di }\end{array}$ http://www.antarajatim.com/lihat/berita/121224/penyerapan-apbd-trenggalekbaru-50-persen

Dogan, M. 2013. "Does firm size affect the firm profitability? Evidence from Turkey". Research Journal of Finance and Accounting 4(4): 53-59.

Eriyanto. 2007. "Pilkada dan pemerintahan yang terbelah (divided government)". Kajian Bulanan Lingkaran Survai Indonesia 7, 1-24. Tersedia di https://www.researchgate.net/profile/Nyarwi_Ahmad/publication/235990129 


\section{_LINGKARAN_SURVEI_INDONESIA/links/O0b7d51544f145f627000000/LI NGKARAN-SURVEI-INDONESIA.pdf-.}

Essien, A. V. 2012. "Human development and good governance (Nigerian Case; 19962010)".SSRN Electonic Journal. Diakses 8 Mei 2015. Tersedia di https://papers.ssrn.com/sol3/papers.cfm?abstract_id=2150466

Farouk, M. A., dan S. U. Hassan. 2014. "Audit quality and financial performance of quoted cement firms in Nigeria". International Journal of Accounting and Taxation 2(2): 01-22.

Florida, A. 2006. "Pengaruh pendapatan asli daerah (PAD) terhadap kinerja keuangan Pemerintah Kabupaten Kota di Propinsi Sumatera Utara”. Tesis. Pasca Sarjana Universitas Sumatera Utara.

Giligan, T. W., dan J. G. Matsusaka. 2001. "Fiscal policy, legislature size, and political parties: Evidence from state and local governments in the first half of the 20th Century". National Tax Journal 54(1): 57-82.

Greiling, D. 2005. "Performance measurement in the public sector: The German experience". International Journal of Productivity and Performance Management 54(7): 551-567.

Gwey, M. O., dan J. Karanja. 2014. "Effect of financial leverage on financial performance of deposit taking savings and credit co-operative in Kenya". International Journal of Academic Research in Accounting, Finance and Management Sciences 4(2): 180-188.

Hambrick, D. C., dan P. A. Mason. 1984. "Upper echelons: The organization as a reflection of its top managers". The Academy of Management Review 9(2): 193-206.

Haniffa, R. M., dan T. E. Cooke. 2005. "The impact of culture and governance on corporate social reporting". Journal of Accounting and Public Policy 24: 391430.

Hasibuan, A. N. 2009. "Pengaruh karakteristik perusahaan dan ekonomi makro terhadap return saham LQ-45 di Bursa Efek Indonesia”. Tesis. Universitas Sumatera Utara.

Hendri, M. 2015. “Ayo jujur, dimana prestasi Ahok pimpin DKI?.” Kompasiana. $\begin{array}{lllll}\text { Diakses } & 27 & \text { Juli } & 2015 . & \text { Tersedia di }\end{array}$ http://www.kompasiana.com/www.lewotana.com/ayo-jujur-dimana-prestasiahok-pimpin-dki

Ilmie, M. I. 2011. "FPKNU sesalkan rendahnya penyerapan APBD”. Antara News. $\begin{array}{lllll}\text { Diakses } & 27 & \text { Juli } & 2015 . & \text { Tersedia di }\end{array}$ http://jatim.antaranews.com/lihat/berita/71300/fpknu-sesalkan-rendahnyapenyerapan-apbd 
Jensen, M. C., dan W. H. Meckling. 1976. "Theory of the firm: Managerial behavior, agency costs and ownership structure". Journal of Financial Economics 3(4): 305-360.

Julitawati, E., Darwanis, dan Jalaluddin. 2012. "Pengaruh pendapatan asli daerah (PAD) dan dana perimbangan terhadap kinerja keuangan pemerintah kabupaten/kota di Provinsi Aceh". Jurnal Akuntansi Pasca Sarjana Universitas Syah Kuala 1(1): 1-15.

Khalifa, M. K., dan Z. Shafii. 2013. "Factros affecting the financial performance of non-oil industrial companies listed on Libyan Stock Market (LSM)". Proceeding. International Conference on Business and Economic Research.

Lasward, F., R. Fisher, dan P. Oyelere. 2005. "Determinant of voluntary internet financial reporting by local government authorities". Journal of Accounting and Public Policy 24: 101-121.

Liargovas, P., dan K. Skandalis. 2010. "Factors affecting firm competitiveness: The case of Greek industry". European institute Journal 2(2): 184-197

Ludjianto, S. E., S. R. Handayani, dan R. R. Hidayat. 2014. "Pengaruh analisis leverage terhadap kinerja keuangan perusahaan (Studi pada perusahaan property dan real estate yang listing di BEI tahun 2010-2012)". Jurnal Administrasi Bisnis 8(1): 1-8.

Magoutas, A., G. M. Agiogiamanarkis, dan T. Papadogonas. 2011. "Education and firm performance: Empirical evidence from Greece". International Journal of Economic Research 8(2): 141-152.

Marimuthu, M., L. Arokiasamy, dan M. Ismail. 2009. "Human development and its impact on firm performance: Evidence from developmental economics". The Journal of International Social Research 2(8): 256-272.

Mock, T. J., J. L. Turner, G. L. Gray, dan P. J. Coram. 2009. "The Unqualified Auditor's Report: A Study of User Perceptions, Effects on User Decisions and Decision Processes, and Directions for Further Research". A Revision of The Summary Report Presented to The Auditing Standards Board and The International Auditing and Assurance Standards Board. Diakses 3 Juni 2015. Tersedia http://www.ifac.org/system/files/downloads/Study____ASB_Summary_Repo rt.pdf

Mon, C. 2015. “Terbukti merugikan negara Rp103,532 Miliar”. Hukumonline. Diakses 27 Juli $2015 . \quad$ Tersedia di http://www.hukumonline.com/berita/baca/hol18181/terbukti-merugikannegara-rp103532--miliar-syaukani-divonis-rendah 
Mukjizat. 2015. "Pelaksanaan APBD TA 2015". Materi rapat kerja teknis pengendalian APBD tahun anggaran 2015 pemerintah kota Surabaya. Website Pemerintah Kota Surabaya. (Bagian Administrasi Pembangunan). Diakses 27 Juli 2015. Tersedia di https://bp.surabaya.go.id/

Mustikarini, W. A. dan D. Fitriasari. 2012. "Pengaruh karakteristik pemerintah daerah dan temuan audit BPK terhadap kinerja pemerintah daerah kabupaten/kota di Indonesia tahun anggaran 2007”. Simposium Nasional Akuntansi XV. Banjarmasin.

Okpala, K. E. 2012. "Audit comitte and integrity of financial statements: A preventive mechanism for corporate failure". Australian Journal of Business and Management Research 2(8): 32-40.

Omondi, M. M., dan W. Muturi. 2013. "Factor affecting the financial performance of listed companies at the Nairobi Securities Exchange in Kenya”. Research Journal of Financial and Accounting 4(15): 99-104.

Papadogonas, T. A. 2007. "The financial performance of large and small firms: Evidence from Greece". International Journal of Financial Services Management 2(1/2): 14-20.

Patrick, P. A. 2007. "The determinant of organizational inovativeness: The adoption of GASB 34 in Pennsylvania local dovernment". Ph.D Dissertation. The Pennsylvania State University.

Pervan, M., dan J. Visic. 2012. "Influence of firm size on its business success". Croatan Operational Research Review (CORR) 3: 213-223.

Priyasidharta, D. (2011). "Eks Bupati Lumajang dituntut lima tahun penjara”.Tempo. $\begin{array}{lllll}\text { Diakses } & 27 & \text { Juli } & 2015 . & \text { Tersedia }\end{array}$ di http://nasional.tempo.co/read/news/2011/05/24/180336453/eks-bupatilumajang-dituntut-lima-tahun-penjara

Republik Indonesia. 1999. "Undang-Undang Nomor 25 Tahun 1999 tentang Perimbangan Keuangan Pemerintah Pusat dan Daerah".

2004. "Undang-Undang Nomor 32 Tahun 2004 tentang Pemerintah Daerah".

2004. "Undang-Undang Nomor 33 tahun 2004 tentang Perimbangan Keuangan Pemerintah Pusat dan Daerah”.

2008. "Peraturan Pemerintah Nomor 6 Tahun 2008 tentang Pedoman Evaluasi Penyelenggaraan Pemerintah Daerah”.

2009. "Peraturan Pemerintah Dalam Negeri Nomor 73 Tahun 2009 tentang Tata Cara Pelaksanaan Evaluasi Kinerja Penyelenggaraan Pemerintah Daerah". 
Seeba, A. A., J. Wallace, dan N. Cornelius. 2009. "Managerial characteristics, strategy and performance in local government”. Measuring Business Excellence 13(4): $12-21$.

Setyaningrum, D., dan F. Syafitri. 2012. "Analisis pengaruh karakteristik pemerintah daerah terhadap tingkat pengungkapan laporan keuangan”. Jurnal Akuntansi dan Keuangan Indonesia 9(2): 154-170.

Simanulang, G. 2013. "Pengaruh belanja modal, intergovermental revenue dan pendapatan asli daerah terhadap kinerja keuangan daerah kota dan kabupaten di Provinsi Kepulauan Riau tahun 2008-2012”. Umrah Journal of Accounting 1(1): $1-24$.

Sudarsana, H. S., dan S. N. Rahardjo. 2013. "Pengaruh karakteristik pemerintah daerah dan temuan audit BPK terhadap kinerja pemerintah daerah (Studi pada pemerintah kabupaten/kota di Indonesia)". Journal of Accounting 2(4): 1-13.

Suhardjanto, D. 2010. "Corporate governance, karakteristik perusahaan dan evironmental disclosure". Prestasi 6(1): 39-69.

Suhardjanto, D., dan R. R. Yulianingtyas. 2011. "Pengaruh karakteristik pemerintah daerah terhadap kepatuhan pengungkapan wajib dalam laporan keuangan pemerintah daerah”. Jurnal Akuntansi 8(1): 1-94.

Sularso, H., dan Y. E. Restianto. 2011. "Pengaruh kinerja keuangan terhadap alokasi belanja modal dan pertumbuhan ekonomi kabupaten/kota di Jawa Tengah". Media Riset Akuntansi 1(2): 109-124.

Sutaryo., dan Carolina. 2014. "Ketepatan waktu penetapan anggaran pendapatan dan belanja daerah pemerintah daerah di Indonesia”. Simposium Nasional Akuntansi XVII. Mataram.

Winarna, J., dan S. Murni. 2007. "Pengaruh personal background, political background, dan pengetahuan dewan tentang anggaran terhadap peran DPRD dalam pengawasan keuangan daerah (Studi kasus di Karesidenan Surakarta dan Daerah Istimewa Yogyakarta Tahun 2006)". Simposium Nasional Akuntansi X. Makassar.

Wiersema, M. F., dan K. A. Bantel. 1992. "Top management team demography and corporate strategic change”. Academy of Management Journal 35(1): 91-121.

Zirman, E. D., dan R. M. Rozi. 2010. "Pengaruh Kompetensi Aparatur Pemerintah Daerah, Penerapan Akuntabilitas Keuangan, Motivasi Kerja, dan Ketaatan Pada Peraturan Perundangan terhadap Akuntabilitas Kinerja Instansi Pemerintah". Jurnal Ekonomi 18(1): 1-12. 
Tabel 5

Definisi Operasional dan pengukuran Variabel

\begin{tabular}{|c|c|c|}
\hline Nama & Definisi Operasional & Pengukuran \\
\hline \multicolumn{3}{|c|}{ Variabel Dependen } \\
\hline Kinerja & (KPPD) adalah capaian atas urusan pemerintah daerah & Menggunakan \\
\hline $\begin{array}{l}\text { Penyelenggara } \\
\text { an Pemerintah }\end{array}$ & $\begin{array}{l}\text { yang diukur dari masukan, proses, keluaran, hasil, } \\
\text { manfaat dan dampak (PP No.6 tahun } 2008 \text { tentang }\end{array}$ & $\begin{array}{l}\text { berdasarkan SK Kemendagri } \\
\text { tentang Penetapan peringkat dan }\end{array}$ \\
\hline $\begin{array}{l}\text { Daerah } \\
(\text { KPPD })\end{array}$ & Evaluasi Penyelenggaraan Pemerintah Daerah) & $\begin{array}{l}\text { status kinerja penyelenggaraan } \\
\text { pemerintah daerah. }\end{array}$ \\
\hline \multicolumn{3}{|c|}{ Variabel Independen } \\
\hline Pengalaman & $\begin{array}{l}\text { Masa jabatan kepala daerah merupakan tenggang } \\
\text { waktu seseorang kepala daerah memegang jabatan } \\
\text { sebagai kepala daerah terhitung sejak dilantik. }\end{array}$ & $\begin{array}{l}\text { Jumlah lama waktu kepala daerah } \\
\text { menjabat sampai periode } \\
\text { penelitian. }\end{array}$ \\
\hline Kompetensi & $\begin{array}{l}\text { Manajer yang berlatar pendidikan keuangan atau } \\
\text { akuntansi mendukung anggaran yang lebih detail dan } \\
\text { teliti yang menunjukkan bahwa manajer yang } \\
\text { memiliki latar belakang pendidikan keuangan atau } \\
\text { akuntansi dapat mengembangkan dan menciptakan } \\
\text { kinerja yang lebih tinggi. }\end{array}$ & $\begin{array}{l}\text { Indikator variabel adalah jika } 1 \\
\text { kalau kepala daerah mempunyai } \\
\text { latar belakang ekonomi } \\
\text { bisnis/akuntansi dan } 0 \text { jika kepala } \\
\text { daerah tidak dari latar belakang } \\
\text { ekonomi. }\end{array}$ \\
\hline Pengawasan & Pengawasan legislatif digambarkan dengan & $\begin{array}{lll}\text { Jumlah } & \text { partai } & \text { pengusung }\end{array}$ \\
\hline legislatif & $\begin{array}{l}\text { komposisi anggota DPRD yang mendukung } \\
\text { pemilihan kepala daerah. }\end{array}$ & $\begin{array}{l}\text { pemilihan kepala daerah yang } \\
\text { diperoleh dari buku profil kepala } \\
\text { daerah kemendagri. }\end{array}$ \\
\hline \multicolumn{3}{|c|}{ Variabel kontrol } \\
\hline \multirow[t]{2}{*}{ Ukuran (size) } & $\begin{array}{l}\text { Aset daerah merupakan sumber daya pemerintah } \\
\text { daerah. Ukuran aset suatu daerah dapat mempengaruhi } \\
\text { kinerja keuangan dalam banyak hal. }\end{array}$ & $\begin{array}{l}\text { Jumlah aset tiap-tiap daerah. } \\
\text { Jumlah anggota DPRD yang } \\
\text { ditetapkan dengan SK Komisi }\end{array}$ \\
\hline & $\begin{array}{l}\text { Ukuran DPRD adalah jumlah anggota Dewan } \\
\text { Perwakilan Rakyat (DPRD) tiap daerah }\end{array}$ & Pemilihan Umum (KPU) \\
\hline Kemakmuran & $\begin{array}{l}\text { Kemakmuran suatu daerah digambarkan dari } \\
\text { kemampuan pemerintah daerah dalam memperoleh } \\
\text { Pendapatan Asli Daerah (PAD). }\end{array}$ & Jumlah PAD tiap-tiap daerah. \\
\hline Leverage & $\begin{array}{l}\text { Leverage yang digunakan dalam penelitian ini } \\
\text { merupakan perbandingan jumlah kewajiban dengan } \\
\text { jumlah ekuitas. }\end{array}$ & $\begin{array}{l}\text { Menggunakan perbandingan } \\
\text { jumlah kewajiban dengan jumlah } \\
\text { ekuitas. }\end{array}$ \\
\hline \multicolumn{3}{|c|}{ Kualitas pengelolaan keuangan } \\
\hline $\begin{array}{l}\text { Kelemahan } \\
\text { SPI }\end{array}$ & $\begin{array}{l}\text { Sistem Pengendalian Internal adalah proses yang } \\
\text { integral pada tindakan dan kegiatan yang dilakukan } \\
\text { secara terus-menerus oleh pimpinan dan seluruh } \\
\text { pegawai untuk memberikan keyakinan memadai atas } \\
\text { tercapainya tujuan organisasi melalui kegiatan yang } \\
\text { efektif dan efisien }\end{array}$ & $\begin{array}{l}\text { Jumlah kasus temuan kelemahan } \\
\text { Sistem Pengendalian Internal } \\
\text { (SPI). }\end{array}$ \\
\hline $\begin{array}{l}\text { Ketidakpatuha } \\
\mathrm{n} \quad \text { terhadap } \\
\text { ketentuan } \\
\text { perundang- } \\
\text { undangan }\end{array}$ & $\begin{array}{l}\text { Temuan ketikpatuhan terhadap ketentuan perundang- } \\
\text { undangan merupakan bagian dari pemberian opini } \\
\text { BPK. }\end{array}$ & $\begin{array}{l}\text { Jumlah kasus kerugian daerah, } \\
\text { potensi kerugian daerah, } \\
\text { kekurangan } \\
\begin{array}{l}\text { administrasi, kenerimaan, } \\
\text { ketidakefisienan }\end{array} \\
\text { ketidakefektifan. }\end{array}$ \\
\hline $\begin{array}{l}\text { Pengawasan } \\
\text { Masyarakat }\end{array}$ & $\begin{array}{l}\text { Pengawasan masyarakat dikaitkan dengan tingkat } \\
\text { pendidikan masyarakat, yang dalam hal ini } \\
\text { ditunjukkan dengan Indek Pembangunan Manusia } \\
\text { (IPM). }\end{array}$ & $\begin{array}{l}\text { Nilai Indek Pembangunan } \\
\text { Manusia (IPM) yang dipublikasin } \\
\text { melalui website BPS Provinsi } \\
\text { Jawa Timur. }\end{array}$ \\
\hline
\end{tabular}


